\title{
Taxonomic and numeric structure of Chironomidae (Diptera) in different habitats of a Neotropical floodplain
}

\author{
Cristina Márcia de Menezes Butakka1 ${ }^{1}$ Luiz Carlos Gomes² \& Alice Michiyo Takeda²
}

\footnotetext{
1. Celbe (Centro de Pesquisa em Limnologia, Biodiversidade e Etnobiologia do Pantanal), Av. Santos Dumont, s/n, Cidade Universitária, Bloco II, $78200-000$ Cáceres, MT, Brazil. (cristinabutakka@terra.com.br)

2. Universidade Estadual de Maringá, Departamento de Biologia (DBI), Nupelia (Núcleo de Pesquisa em Limnologia, Ictiologia e Aquicultura), Av. Colombo, 5790, $87020-900$ Maringá, PR, Brazil. (alice@nupelia.uem.br)
}

\begin{abstract}
We characterized the local benthic Chironomidae by analyzing the numerical density, biomass, diversity index of Shannon-Wiener and dominance of larvae in the main channel of the Ivinhema River, in a secondary channel, in five lakes connected to the main channel and in five lakes without connection. Of the 68 taxa identified, Aedokritus sp., Tanytarsus sp., Chironomus strenzkei Fittkau, 1968 and Procladius sp.1 were found in all sampling sites and were considered morphospecies with greater of greatest ecological plasticity. Chironomus strenzkei Fittkau, 1968, contributed with the greatest biomass in the central region of lakes without connection, whereas Aedokritus sp. dominated in the littoral of lakes. The greater values of diversity indices in the littoral region of channels were due to the greater water flow and to the higher food availability in these areas. The dominance indices, by contrast, were greater on the central region of these environments. The littoral region has exclusive characteristics, representing habitats that could play important controlling in the numerical density and index diversity on the ecosystem, whereas that the biomass of benthic invertebrates in the central region in some biotopes would have different spatial probably according organisms drift.
\end{abstract}

KEYWORDS. Chironomidae larvae, biomass, diversity, dominance, Paraná River.

RESUMO. Estrutura taxonômica e numérica de Chironomidae (Diptera) em diferentes habitats de uma várzea neotropical. As larvas de Chironomidae foram caracterizadas localmente para analisar a densidade, biomassa, índice de diversidade de Shannon-Wiener e dominância no canal principal do Rio Ivinhema, em um canal secundário, em cinco lagoas conectadas ao canal principal e cinco lagoas sem conexão. Dos 68 taxa, Aedokritus sp., Tanytarsus sp., Chironomus strenzkei Fittkau, 1968 e Procladius sp.1 foram encontrados em todos os locais de amostragem e foram consideradas as morfoespécies com a maior plasticidade ecológica. Chironomus strenzkei contribuiu com a maior biomassa na região central das lagoas sem conexão, enquanto que Aedokritus sp. dominou na região litorânea das lagoas. Os maiores valores do índice de diversidade na região litorânea dos canais foram pertinentes ao maior fluxo de água e disponibilidade de alimento nessas áreas. Os índices de dominância, em contraste, foram maiores na região central desses ambientes. A região litorânea tem características exclusivas, com habitats que apresentaram um importante papel no controle da densidade numérica e índice de diversidade no ecossistema, enquanto que a biomassa dos invertebrados bentônicos na região central em alguns biótopos pode ter diferenças espaciais de acordo com a deriva de organismos.

PALAVRAS-CHAVE. Larvas de Chironomidae, biomassa, diversidade, dominância, Rio Paraná.

The floodplain of the Upper Paraná River is made up of a great number and variety of aquatic environments, such as channels and marginal lakes (StevauX et al., 2004), with distinct transitional habitats which aid in the maintenance of a high biodiversity (THomaz et al., 2004). The diversity of water bodies of the floodplain has triggered studies on benthic invertebrates, notably Chironomidae larvae, such as the studies of MARCHESE et al. (2002, 2005), CAPELLO et al. (2004), Ezcurra de Drago et al. (2004) and Bletter \& MARCheSE (2005). HiguTi \& TAKEDA (2002) concentrate on the distribution and numerical densities of genera, HiguTi (2004) about species richness and dominance and about trophic conditions in reservoirs (TAKAHASHI et al., 2008) and in the Middle Paraná River floodplain (GALızzi et al., 2012)

All of these studies underline the importance of hydrodynamics as the main determining factor in the numerical fluctuations and of the spatial and temporal variation of species encountered in the floodplain of the Upper Paraná River.

The family Chironomidae is extraordinarily rich in species and occurs in a broad variety of habitats, defining a variable role in the ecosystems and the possibility of interactions with different types of organisms (McKIE \& Pearson, 2006). Its success in the adaptation to diverse types of environments is due to a broad limit of trophic exploration and of micro-spatial aspects of the systems where it occurs (Dimitriadis \& CRANSTON, 2007).

In Brazil, a major part of the studies are of taxonomic inventories (STUR et al., 2006; CoRreia et al., 2005, 2006; Correia \& Trivinho-Strixino, 2007; Trivinho-Strixino \& Strixino, 2005, 2008), association with habitats types (Suriano \& Fonseca-Gessner, 2004; Sanseverino \& Nessimian, 2008) or deal with the distribution of larvae in different habitats (HeNRiques-Oliveira et al., 2003; AMORIM et al., 2004) and larval biomass (CALLISTO et al., 2002).

Studies about the attributes of groups are indispensable to complement the understanding of community structure, as well as the functioning of aquatic ecosystems (CLARKe et al., 2008; Rose et al., 2008; HaHN \& FuCHS, 2009).

This study had as main objective to characterize and differentiate, on a local scale, the habitats (littoral region and central region) and the different types of environments and seasons (main channel, secondary channel, lakes with 
and without connection to the river), from estimations of the numerical density, of the biomass, of the diversity indices and of the dominance index of benthic Chironomidae.

We expected that (i) the values of biomass and of the diversity indices can be greater in the littoral region than in the central region, and (ii) greater in lakes wit connection to the river than in those without connection.

\section{MATERIALS AND METHODS}

Study area. The study area is situated in the state of Mato Grosso do Sul, in the Upper Paraná River floodplain. The Ivinhema River is one of the main tributaries of the right bank of the river. The Curutuba channel connects the Ivinhema River to the Baía River, and the channel Ipoitã connects directly the Ivinhema River to the Paraná River (Souza Filho et al., 2004; Souza Filho \& Stevaux, 2004).

The inundated areas of the Upper Paraná River are influenced by the main channel, including the floodplain which is an important source of energy for lacustrine environments. The Paraná River itself, the islands, secondary channels and floodplains, as the marginal lagoons, are systems that are structurally and functionally directly dependent on the horizontal water flow, which form a functional ecological connection with the main course of the river.

In this stretch of river four types of environments were sampled at twelve sampling sites (Fig. 1): CAP, main channel; CAS, secondary channel; LCC, lakes with connection to the river; LSC, lakes without such a connection. The main channel is formed by the Ivinhema River (RI); the secondary channel by the Canal
Ipoitã (CI); the lakes with connection to the main river are: Patos (PA), Sumida (SU), Finado Raimundo (FR), Boca do Ipoitã (BI) and Peroba (PE). Lakes without connection are: Cervo (CE), Jacaré (JA), Capivara (CA), Zé do Paco (ZP) and Ventura (VE).

The main and secondary channels are different from the lakes in having greater oxygen content. Temperature, $\mathrm{pH}$ (slightly neutral) and the electric conductivity of the water have similar mean values in the environments, with little variability (Tab. I).

Data sample. Samples of larvae were taken every three months, resulting in three replicas for each station. The sediment was collected with a modified Petersen grab $\left(0.0189 \mathrm{~m}^{2}\right)$, between February 2000 and May 2001. In the field the samples were washed and collected, using a set of sieves with mesh size of $2.0 \mathrm{~mm}, 1.0 \mathrm{~mm}$ and $0.2 \mathrm{~mm}$. Organisms picked from the first two sieves were collected and immediately fixed in $70 \%$ alcohol. The sampled taken from the last sieve was store in flasks with $70 \%$ alcohol for later selection in the laboratory. After the selection the larvae were determined to the genera level, and, whenever possible, to specific level. For identification were used the keys of Coffman \& Ferrington (2008) and TrivinhoStRIXINO \& STRIXINo (2011).

The larvae from the different sieves were counted as an estimation of their numerical density, and measured separately, after being mounted on slides, for a later determination of their biomass. For the estimation of biomass, 3,508 individuals were examined, about $40 \%$ of the total sample. Chironomidae larvae have a cylindrical and elongated body, which allows the determination of their biovolume. Starting from this, a geometric

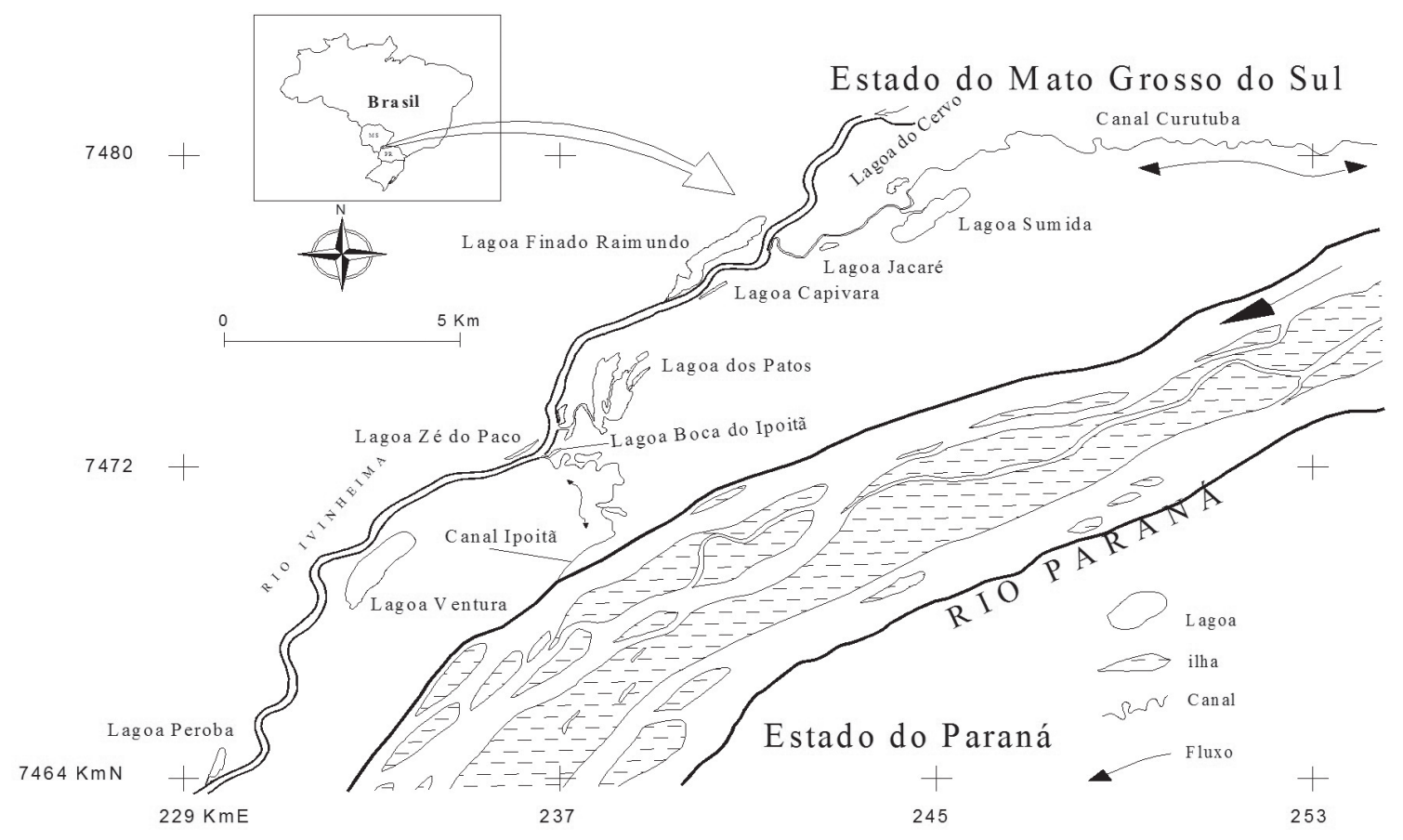

Fig. 1. Localization of the study area and the sampling sites. 
Tab. I. Mean values and standard deviation of abiotic variables in the habitats of the four types of environments of the Invinhema River [CAP, main channel; CAS, secondary channel; LCC, lakes with connection to the river; $\mathrm{LSC}$, lakes without connection; Depth $(\mathrm{m})$; Temp, temperature $\left({ }^{\circ} \mathrm{C}\right)$; Cond, electric conductivity; DO, dissolved oxygen].

\begin{tabular}{lcccccc}
\hline Environments & Habitats & depth $(\mathrm{m})$ & Temp $\left({ }^{\circ} \mathrm{C}\right)$ & $\mathrm{pH}$ & Cond $(\mu \mathrm{S} / \mathrm{cm})$ & $\mathrm{DO}(\mathrm{mg} / \mathrm{l})$ \\
\hline CAP & & $1.56( \pm 0.63)$ & $25.00( \pm 3.56)$ & $6.72( \pm 0,38)$ & $42.92( \pm 2.22)$ & $6.95( \pm 0.87)$ \\
CAS & Littoral region & $1.07( \pm 0.94)$ & $25.24( \pm 3.49)$ & $7.01( \pm 0,65)$ & $52.21( \pm 5.64)$ & $8.33( \pm 1.91)$ \\
LCC & $1.01( \pm 0.57)$ & $25.01( \pm 3.74)$ & $6.44( \pm 0,46)$ & $39.60( \pm 5.67)$ & $5.74( \pm 1.62)$ \\
LSC & & $1.49( \pm 0.90)$ & $24.96( \pm 3.58)$ & $6.35( \pm 0,53)$ & $42.69( \pm 14.14)$ & $4.84( \pm 1.81)$ \\
CAP & & $4.08( \pm 0.34)$ & $25.00( \pm 3.86)$ & $6.80( \pm 0,22)$ & $42.83( \pm 2.5)$ & $7.42( \pm 0.94)$ \\
CAS & & $2.81( \pm 1.25)$ & $25.23( \pm 3.73)$ & $6.91( \pm 0,16)$ & $51.63( \pm 5.25)$ & $8.33( \pm 2.04)$ \\
LCC & Central region & $3.27( \pm 0.72)$ & $24.69( \pm 3.89)$ & $6.45( \pm 0,43)$ & $38.43( \pm 10.81)$ & $4.89( \pm 1.81)$ \\
LSC & & $2.90( \pm 1.19)$ & $24.62( \pm 3.47)$ & $6.40( \pm 0,59)$ & $48.53( \pm 22.35)$ & $4.65( \pm 2.06)$ \\
\hline
\end{tabular}

model was used for the calculation of the biovolume, as an estimation of their approximate biomass, in accordance with the formula proposed by SMIT et al. (1993). Considering the density of the larvae from previously selected points, the total biomass was calculated for each habitat, season and type of environment.

The community structure was characterized using the diversity index of Shannon-Wiener (H') (Pielou, 1975) and the dominance index from the taxonomic composition and density of the taxa. The diversity index was calculated for each type of environment and for the habitats.

The dominance index was calculated as a component of diversity using this unit minus the uniformity value ( 1 - U), considering only environments and habitats. The dominance index was calculated with the formula of KOWNACKI (1971).

The values of the index differentiate two groups: dominants $(10<\mathrm{d}<100)$ and subdominants $(1<\mathrm{d}<9.99)$.

To test the differences between the means of numerical densities, of biomass, of indices of diversity and dominance, taking as variable factors the environments, the sites and the habitats, a non-parametrical analysis of Kruskal-Wallis was used, because the requirements were not reached. LSD a posteriori was used for verification which of the environmental variables differs in relation to the diversity values.

\section{RESULTS}

Abiotic analyses. A total of 8,571 Chironomidae larvae were analyzed, which belong to three subfamilies, nine tribes and 68 taxa. Chironominae (47 taxa) were the most abundant, with prevailing Chironomini (43 taxa), which represent $63 \%$ of all identified tribes. Pentaneurini contributed with $12 \%$ of the sampled larvae, while larvae of Orthocladiinae contributed 7\% (Fig. 2).

Of 68 sampled taxa, 12 were found exclusively in lakes without connection to the river (Parachironomus sp. 1, Parachironomus sp. 3, Parachironomus sp. 4, Zavreliella sp. 1, Ablabesmyia (Karelia) sp., Dicrotendipes sp. 3, Corynoneura sp. 2, Chironomus gr. decorus sp. II, Gênero C, Lauterborniella sp., Thienemanniella sp. 1 and Microchironomus sp.) and only three in lakes with connection (Chironomus gr. riparius, Pelomus sp. 3 e Labrundinia sp. 1). The larvae of Cricotopus sp. 2, Endotribelos sp. 2 and Endotribelos sp. 3 were exclusive in the two channels, while Apedilum sp. and Larsia sp. occurred only in the main channel of the Ivinhema River.

Aedokritus sp., Tanytarsus sp., Chironomus strenzkei Fittkau, 1968 and Procladius sp. 1 recorded from all sampling sites (Tab. II).

Despite the tendency of the mean numerical density to increase from the lotic environment to the more lentic
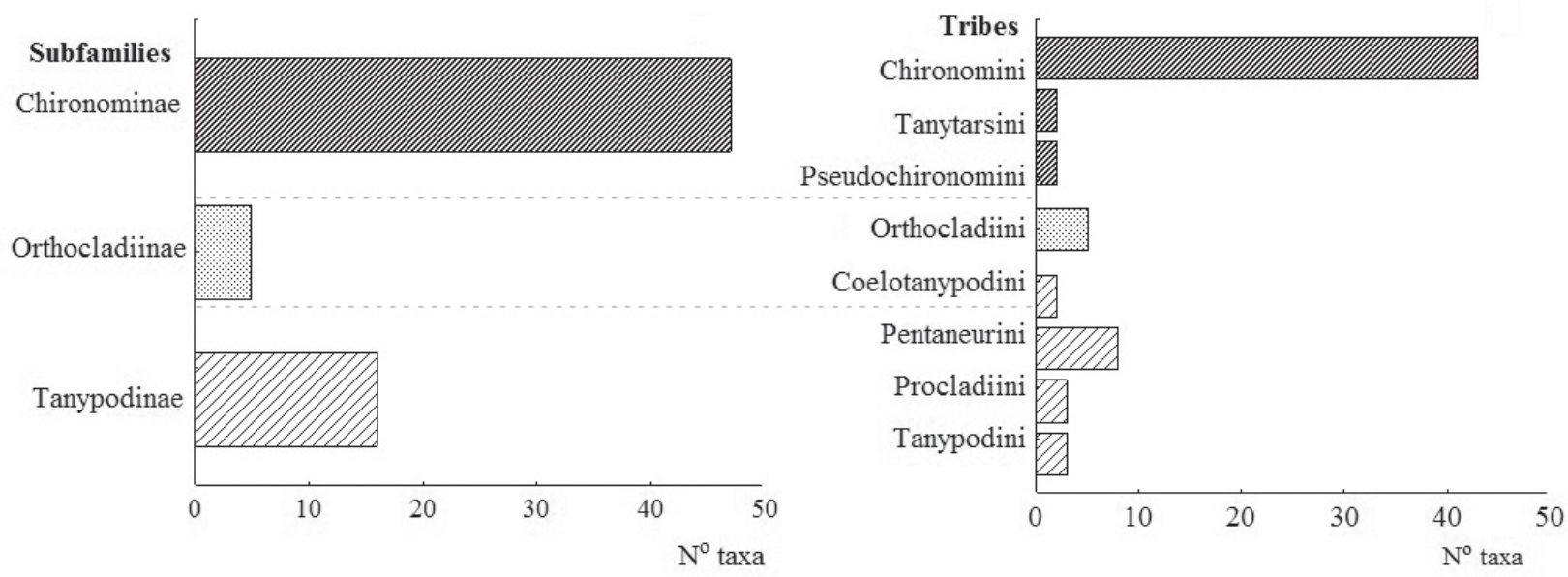

Fig. 2. Number of taxa of Chironomidae for each subfamily and tribe. 


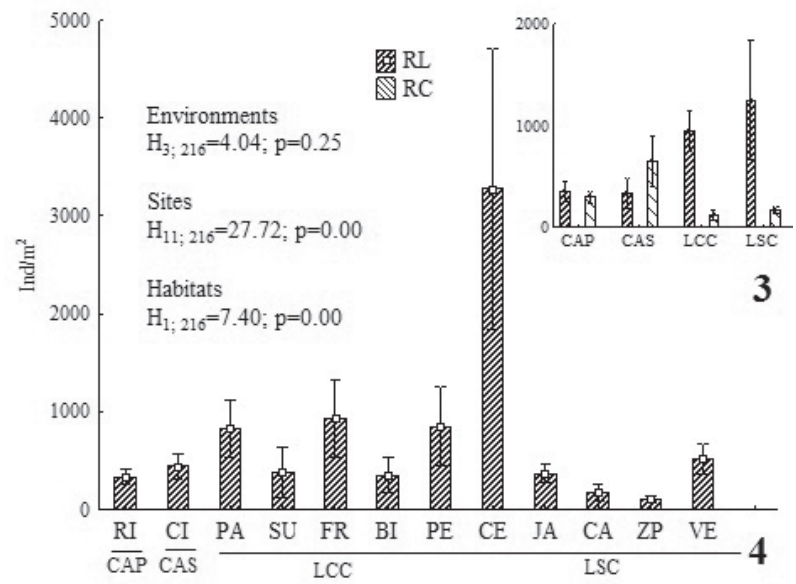

Figs 3, 4. Mean numerical densities and standard errors, resp., in four types of environments (3) and in twelfe sampling sites (4) (CAP, main channel; CAS, secondary channel; LCC, lakes with connection to the river; LSC, lakes without a connection; RI, Ivinhema River; CI, Channel Ipoitã; PA, Patos Lake; SU, Sumida Lake; FR, Finado Raimundo Lake, BI, Boca do Ipoitã Lake; PE, Peroba Lake; CE, Cervo Lake; JA, Jacaré Lake; CA, Capivara Lake; ZP, Zé do Paco Lake; VE, Ventura Lake; RL, littoral region; $\mathrm{RC}$, central region).

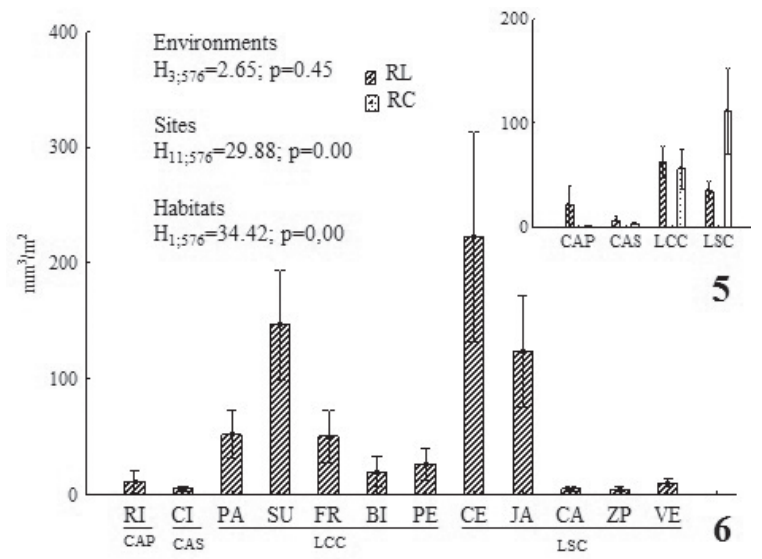

Figs 5, 6. Mean biomass $\left(\mathrm{mm}^{3} / \mathrm{m}^{2}\right)$ and standard error, resp., in four environment types (5) and in twelve sampling sites, Mato Grosso do Sul, Brazil (6), and results of the Kruskal-Wallis analysis, considering them as factors (unifactorial).

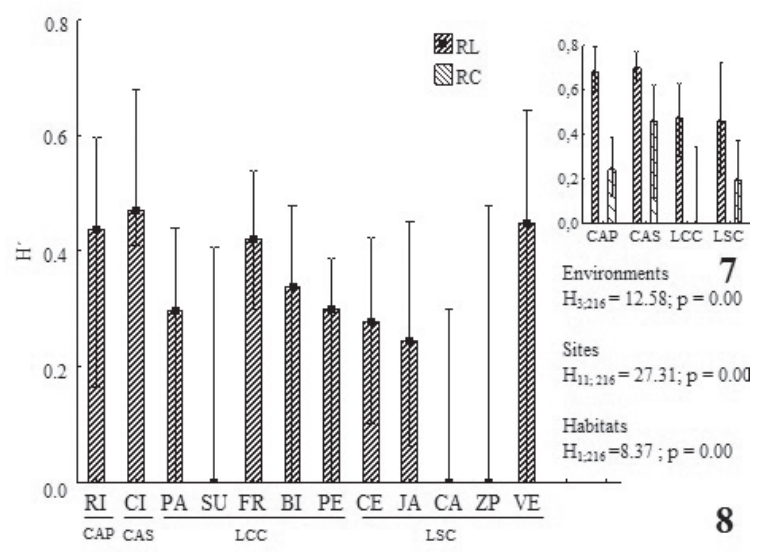

Figs 7, 8. Mean values of diversity index, standard errors, resp., and results of the Kruskal-Wallis analysis, considering environments, habitats (7), and sampling sites, Mato Grosso do Sul, Brazil (8) as factors (unifactorial).
(Fig. 3), the Kruskal-Wallis test did not show significant differences, while between seasons the differences were highly significant, with the highest mean values in the Cervo Lake (Fig. 4).

The lakes have the greatest biomass $\left(\mathrm{mm}^{3} / \mathrm{m}^{2}\right)$ among the environments (due to a greater contribution of C. strenzkei). However, the differences are not significant (Fig. 5). The different habitats, by constrast, show highly significant variability in the mean biomass values, especially in the central region of lakes without connection. At the sampling sites, the mean biomass values were also highly significant (Fig. 6).

Differences between habitats in the diversity index were obvious (Fig. 7), with the highest values in the littoral region, especially in the main and secondary channel, showing highly significant differences (Kruskal-Wallis) for the types of environments, sampling sites (Fig. 8) and habitats.

The lakes without connection and the two channels differed significantly between each other $(\mathrm{p}<0,05$; LSD a posteriori), while lakes with connection differed significantly only from the secondary channel.

The dominance index (considered as a component of the diversity indices: 1-U) didn't show significant differences for environments and habitats (Kruskall-Wallis), though the values were higher in the central region of the channels and in the littoral region of the lakes (Fig. 9). Differences in the dominance index were more marked between sampling sites, showing highly significant differences, with highest values in the Cervo Lake (Fig. 10).

Chironomus strenzkei was dominant in the central region of the lakes (Patos, Sumida, Cervo, Jacaré e Capivara) (dominance index of Kownacki, 1971: 16.6774.91), which had low taxonomic richness (1 to 10 taxa). In the littoral region of the lakes Patos, Finado Raimundo, Boca do Ipoitã, Cervo and Ventura Aedokritus sp. was dominant (14.48-34.07). The second dominant species in

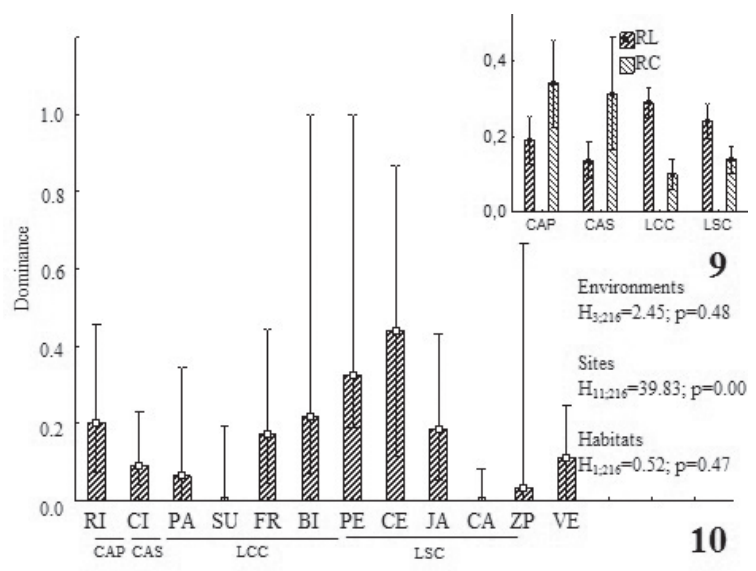

Figs 9, 10. Mean dominance values (1-U) and results of the KruskalWallis analysis, considering environments, habitats (9) and sampling sites, Mato Grosso do Sul, Brazil (10) as factors. 


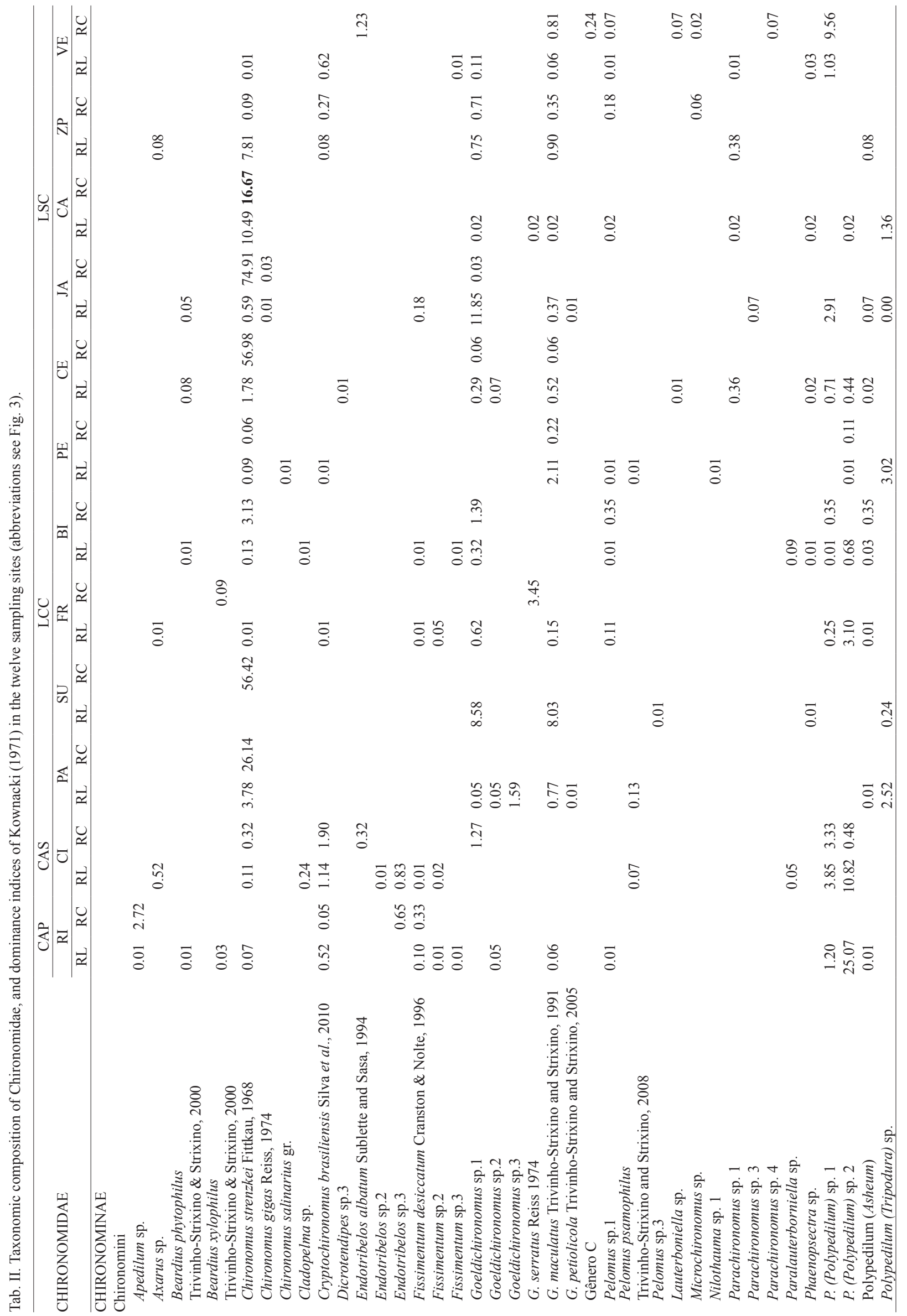




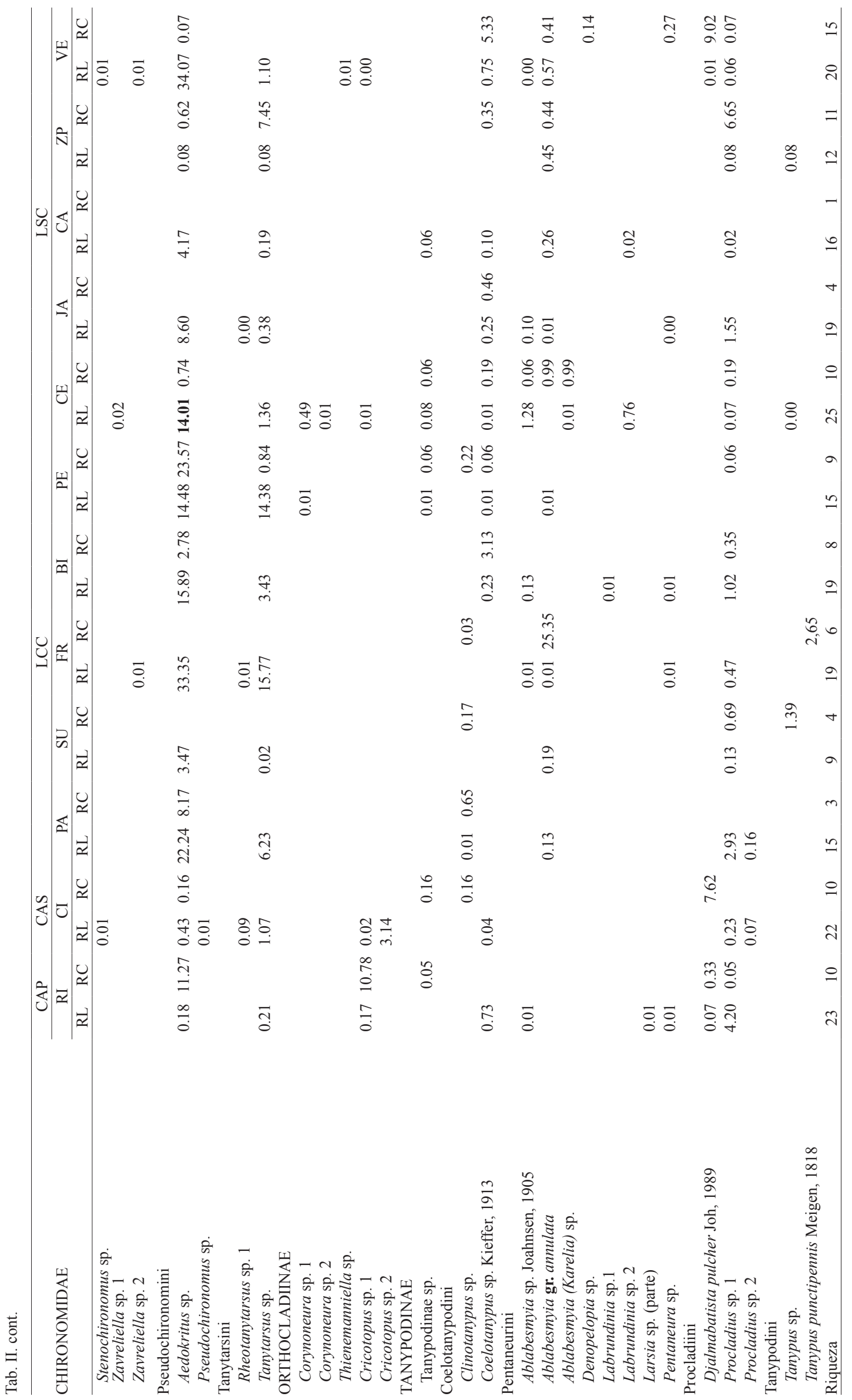


the lakes Finado Raimundo and Peroba was Tanytarsus sp. (15.77 and 14.38, resp.).

Aedokritus sp. (11.27) and Cricotopus sp.1 (10.78) were dominant in the central region of the Ivinhema River, while Polypedilum (Polypedilum) sp. 2 dominated in the littoral region of the two channels. The taxonomic richness was greater in the littoral region of the channels and lakes (Tab. II).

\section{DISCUSSION}

The distinct environmental characteristics of the sampling sites and habitats proved to be determinant for the differences in the population attributes, as well in numerical densities, biomass, and diversity and dominance indices.

Chironomidae larvae of the Ivinhema River mostly belonged to the tribe Chironomini. The abundance of this group in Neotropical regions has been noticed before (Henriques-Oliveira et al., 2003; TAKeda et al., 2004).

The greater numerical densities of Chironomidae larvae in lakes without connection, especially in the Cervo Lake, are probably due to input of organic matter from aquatic macrophytes, which serve as support and shelter, and act particularly as a factor for the increase of the colonization and distribution of larvae.

Aedokritus sp., C. strenzkei, Tanytarsus sp. and Procladius sp.1 were recorded in all sampling sites, and may be considered species with greater ecological plasticity. Marchese et al. (2002), EzCuRRA de Drago et al. (2004) and Higuti \& TAKEDA (2002) also recorded a great abundance of these taxa in floodplain lakes, channels and rivers of the Paraná River. Generally, the numerical densities of larvae increased in response to the dry phase of inundation areas (VERBERK et al., 2008), when they are encountered on the sediment surface of littoral regions of lenthic environments.

Lenthic environments have their distinct hydrodynamic from lotic environments, determined by the inflow from the main channel to the connected lakes, or from the local rainfall conditions, concerning lakes without connection (WANTZEN et al., 2005).

Larvae from the central region of lakes are bigger than larvae from the littoral region. The greater biomass recorded in lakes without connection due to dominance of C. strenzkei in the central region of these environments (significant between habitats) suggests a fundamental role of this species in the maintenance of populations in lentic environments of not connected lakes. Besides C. strenzkei in the Jacaré lake and Chironomus gr. decorus sp. II was also recorded, which increased the biomass value.

According to CALLisTo et al. (2002), the high organic matter content in the sediment of the Imboassica Lagoon, state of Rio de Janeiro, suggests food limitation neither for biomass of the Chironomus larvae nor for Polypedilum in the littoral and limnetic zones, respectively.

The greater values of diversity index and taxonomic richness of Chironomidae larvae observed in the littoral region of the main and secondary channel may be related to the water flow, which lead to an increased oxygenation (Mokany et al., 2008). The velocity of the current creates a mosaic of habitats which are colonized by aquatic communities, influencing the dynamic of the distribution of the Chironomidae fauna.

HENRY (2003) found similar results in the Paranapanema River in relation to marginal lakes for other communities (phytoplancton and zooplancton), confirming that the lacustrine environments have greater hydrological stability than the river. Thus the variability of the current could be a disturbing factor that causes a greater diversity of the fauna by advection of species from the central region to the littoral, which provides shelter and food.

A decisive factor for the greater diversity and species richness could also be the degree of connectivity between the river and lacustrine environment in the floodplain. HENRY (2003) argued that disconnected environments should have a lower number of insect species than connected floodplain ecosystems. However, in the present study, both lakes with connection and lakes without connection reached similar diversity index values, most notably in the littoral region, which is formed by aquatic macrophytes and/or terrestrial vegetation of different physiognomies (SouzA et al., 2004), which contributes to the greater offer of habitats and food.

In habitats with low diversity predominated species most adapted, such as C. strenzkei, which dominated (in mean concentrations of 4.65 a $4.89 \%$ DO) in the central region of different sampling sites. Some Chironomidae species in their aquatic stage have the ability to survive under unfavorable oxygen conditions and adjust to environmental changes. Thus, they can sometimes be the only insects present in the sediment (Solomon et al., 2008), as many species synthesize a respiratory pigment similar to hemoglobin, which transports and stores oxygen (Brodersen et al., 2008). Others, like Aedokritus sp., dominated in the littoral region of lakes and in the central region of lothic environments, showing also their plasticity in relation to the water current velocity.

Another decisive factor for the greater diversity values of Chironomidae larvae in the littoral region of different environments could be the lesser depth in this habitat, with greater proliferation of perifitic algae, as well as greater offer of food resources and autochthonic and allochthonic organic matter than in the central region. This difference reflects in the greater species richness verified in the littoral region of the twelve sites, favorable for the development of many taxa.

Between the twelve sites, the differences in the dominance values were obvious. In the connected lakes like Patos and Sumida, C. strenzkei was dominant in the central region (dominance index 26.14 e 56.42, resp.). Similarly, HiguTI \& TAKEDA (2002) encountered larvae of Chironomus as dominant in the central region of the Patos lake (dominance index 12.20), proving thus, that the low content of dissolved oxygen and the increase of organic matter can be important factors for the colonization of larvae of this genus. 
The dominance of Aedokritus sp. (secondary channel and six lakes), Polypedilum (Polypedilum) sp.2 (main and secondary channel) and Tanytarsus sp. (two lakes with connection) in some sites of the littoral region is possibly due to the habitat characteristics, indicating that these places are favorable for the development of their larvae, defining a fauna more adapted to habitats with an elevated offer of particulate food. In previous studies, TAKEDA et al. (2004) showed that larvae of the genus Polypedilum reached high densities and were dominant in littoral regions of channels and lakes of the floodplain of the Upper Paraná River, in shallow sites with accumulation of detritus, whereas according to MonTALTO \& PAGGI (2006), the larvae increasing when the wetland is disconnecting from the river.

The larvae of Orthocladiinae are generally characteristic of lotic environments and the greater water flow in these sites lead to the dominance of Cricotopus, especially in the central region of the main channel. FÉlix dos Anjos \& TAKEDA (2010), studied invertebrate communities in a lotic tropical environment of the Paraná River, encountered species of Cricotopus, and showed that the patterns of distribution of organisms is not exclusively a consequence of the water turbulence, but the organisms can aggregate in the same place as the organic matter of the substrates.

Some species of the Upper Paraná River floodplain have high ecological plasticity, as eurybiontes, and can live in a wide environmental variability, and formed populations integrated in many biotic communities. The greater diversity indices in lotic environments, besides the better oxygen conditions, can be consequence of the lateral increase of Chironomidae larvae from the hyporheic zone, which incorporates matter and organisms in the littoral habitats. Thus this zone may play an important role in the maintenance of populations in the main and secondary channel.

The population structure and distribution of Chironomidae larvae is distinct in function of the diversity and quantity of floodplain habitats of the Upper Paraná River. This study contributes to the knowledge of new attributes of the Chironomidae fauna, especially the biomass. The data show that the littoral region of the main and secondary channel and of the lakes is characterized as habitat of great importance for the floodplain ecosystem, attributed to the numerical density and diversity of Chironomidae larvae in the system. On the other side, the central region of the lakes serves as entrance for a great quantity of organic matter already processed in the littoral region, increasing the greater biomass of the benthic fauna.

We conclude that changes brought by habitats different were the main factors influencing the attributes of benthic invertebrates originating in the Ivinhema River. The proposed method complements ongoing investigations in the Paraná River including the effect of habitats different on the benthic community. The littoral region has exclusive characteristics, representing habitats that could play important controlling in the numerical density and index diversity on the ecosystem and alterations in the benthic invertebrates may be attributed to the greater heterogeneity of habitats.

The difference in main channel, secondary channel, connected and lakes without connection, may suggest that invertebrate entry into the drift is active, although differences in benthic densities may confound these patterns.

It was presumed that the biomass of benthic invertebrates in the central region in some biotopes would have different spatial probably according invertebrate drift. The reasons behind these differing results are not clear but may be related to life cycle differences among the taxa studied, and differences in the channel and flow amongst the environments.

From these studies it is obvious that the biomass of chironomids is substantially greater than attained in littoral region, and may be related to the lack of fish predators which might otherwise reduce standing crop biomass. In the Paraná River floodplain, new studies should be developed to define species composition, density and biomass benthic community structures, to better characterize habitats and evaluate subsequent aquatic biodiversity.

Acknowledgments. The authors are grateful for the financial support of the LTER (Long Term Ecological Research) project, to CNPq for financial support, to Laboratório de Limnologia Básica of NUPELIA for providing water quality data and, the Parque Estadual de Ivinhema for permission to collect the zoobenthos.

\section{REFERENCES}

Amorim, R. M.; Henriques-Oliveira, A. L. \& Nessimian, J. L. 2004. Distribuição espacial e temporal das larvas de Chironomidae (Insecta: Diptera) na seção ritral do rio Cascatinha, Nova Friburgo, Rio de Janeiro, Brasil. Lundiana 5(2):119-127.

Blettler, M. C. M. \& Marchese, M. R. 2005. Effects of bridge construction on the benthic invertebrates structure in the Paraná river delta. Interciencia 30(2):60-66.

Brodersen, K. P.; Pedersen, O.; Walker, I. R. \& Jensen, M. T. 2008. Respiration of midges (Diptera; Chironomidae) in British Columbian lakes: oxy-regulation, temperature and their role as palaeo-indicators. Freshwater Biology 53:593-602.

Callisto, M.; Moreno, P.; Gonçalves, J. F. JR.; Leal, J. J. F. \& Esteves, F. A. 2002. Diversity and biomass of Chironomidae (Diptera) larvae in an impacted coastal lagoon in Rio de Janeiro, Brazil. Brazilian Journal of Biology 62(1):77-84.

Capello, S.; Marchese, M. \& Ezcurra de Drago, I. 2004. Descomposición y colonización por invertebrados de hojas de Salix humboldtiana en la llanura aluvial del río Paraná medio. Amazoniana 181/2:125-143.

Clarke, A.; Mac Nally, R.; Bond, N. \& LaKe, P. S. 2008. Macroinvertebrate diversity in headwater streams: a Review. Freshwater Biology 53:1707-1721.

Coffman, W. P. \& Ferrington, JR., L. C. 2008. Chironomidae. In: Merrit, R. W. \& Cummins, K. W. eds. An introduction to the Aquatic Insects. Kendall/Hunt, Dubuque. p. 635-754.

Correia, L. C. \& Trivinho-Strixino, S. 2007. New species of Chironomus Meigen (Diptera: Chironomidae: Chironominae) from Brazil. Zootaxa 1504:53-68.

Correia, L. C. S.; Trivinho-Strixino, S. \& Michailova, P. 2005. A new species of Chironomus Meigen, 1803 (Diptera, Chironomidae) from the southeast of Brazil. Studies on Neotropical Fauna and Environment 40:29-38. 
2006. A new species of Chironomus Meigen (Diptera: Chironomidae: Chironominae) from polluted streams of southeastern Brazil. Zootaxa 1130:57-68.

Dimitriadis, S. \& Cranston, P. S. 2007. From the Mountains to the Sea: assemblage structure and dynamics in Chironomidae (Insecta: Diptera) in the Clyde River estuary gradient, New South Wales, southeastern Australia. Australian Journal of Entomology 46(3):188-197.

Ezcurra de Drago, I.; Marchese, M. \& Wantzen, K. M. 2004. Benthos of a large neotropical river: spatial patterns and species assemblages in the Lower Paraguay and its floodplains. Archiv für Hydrobiologie 160(3):347-374

Félix Dos Anjos, A. \& TAKedA, A. M. 2010. Estrutura da comunidade das larvas de Chironomidae (Insecta: Diptera), em diferentes substratos artificiais e fases hídricas, no trecho superior do rio Paraná, Estado do Paraná, Brasil. Acta Scientiarum, Biological Sciences 32(2):131-140.

Galizzi, M. C.; Zilli, F. \& Marchese, M. 2012. Diet and functional feeding groups of Chironomidae (Diptera) in the Middle Paraná River floodplain (Argentina). Iheringia, Série Zoologia 102(2):117-121.

Hahn, J. \& Fuchs, A. 2009. Distribution patterns of groundwater communities across aquifer types in south-western Germany. Freshwater Biology 54:848-860.

Henriques-Oliveira, A. H.; Nessimian, J. L. \& Dorvillé, L. F. M. 2003. Feeding habitats of Chironomid larvae (Insecta: Diptera) from a stream in the Floresta da Tijuca, Rio de Janeiro, Brazil. Brazilian Journal of Biology 63(2):269-281.

HenRY, R. 2003. Os ecótonos nas interfaces dos ecossistemas aquáticos: conceitos, tipos, processos e importância. Estudo de aplicação em lagoas marginais ao rio Paranapanema na zona de sua desembocadura na represa de Jurumirim. In: HENRY, R. ed. Ecótonos nas interfaces dos ecossistemas aquáticos. São Carlos, RiMa. p. 1-28.

Higuti, J. 2004. Composition, abundance e habitats of benthic chironomid larvae. In: Thomaz, S. M.; Agostinho, A. A. \& Hahn, N. S. eds. The Upper Paraná River and its Floodplain: Physical aspects, Ecology and Conservation. Leiden, Backhuys Publishers. p. 209-221.

Higuti, J. \& TAKedA, A. M. 2002. Spatial and temporal variation in densities of chironomid larvae (Diptera) in two lagoons and two tributaries of the upper Paraná river floodplain, Brazil. Brazilian Journal of Biology 62(4B):807-818.

KownACKI, A. 1971. Taxocens of Chironomidae in streams of the Polish High Tatra Mts. Acta Hydrobiologica 13(4):439-464.

Marchese, M.; Ezcurra De Drago, I. \& Drago, E. 2002. Benthic macroinvertebrates and physical habitat relationships in the Paraná River-Floodplain System. In: McClain, M. ed. The Ecohydrology of Southamerican Rivers and Wetlands. International Association Hydrological Sciences 6:111-132.

Marchese, M.; Wantzen, K. M. \& Ezcurra de Drago, I. 2005. Benthic invertebrate assemblages and species diversity patterns of the Upper Paraguay river. River Research and Applications 21:485-499.

McKie, B. G. \& Pearson, R. G. 2006. Environmental variation and the predator-specific responses of tropical stream insects: effects of temperature and predation on survival and development of Australian Chironomidae (Diptera). Oecologia 149:328-339.

Mokany, A.; Wood, J. T. \& Cunningham, S. A. 2008. Effect of shade and shading history on species abundances and ecosystem processes in temporary ponds. Freshwater Biology 53:1917-1928.

Montalto, L. \& PagGi, A. C. 2006. Diversity of chironomid larvae in a marginal fluvial wetland of the Middle Paraná river floodplain, Argentina. Annales de Limnologie - International Journal of Limnology 42(4):289-300.

PIelou, E. C. 1975. Ecological diversity. New York, John Wiley. 165p.

Rose, P.; Metzeling, L. \& CatzikiRis, S. 2008. Can macroinvertebrate rapid bioassessment methods be used to assess river health during drought in south eastern Australian streams? Freshwater Biology 53:2626-2638.

Sanseverino, A. M. \& Nessimian, J. L. 2008. The food of larval chironomids in a stream of the Atlantic Forest (Rio de Janeiro, Brazil). Acta Limnologica Brasiliensia 20:117-130.

Received 19 November 2013. Accepted 25 August 2014. ISSN 0073-4721 Article available at: www.scielo.br/isz
Smit, H.; van Hell, D. \& Wiersma, S. 1993. Biovolume as a toll in biomass determination of Oligochaeta and Chironomidae. Freshwater Biology 29:37-46.

Solomon, C. T.; Carpenter, S. R.; Cole, J. J. \& Pace, M. L. 2008. Support of benthic invertebrates by detrital resources and current autochthonous primary production: results from a whole-lake 13C addition. Freshwater Biology 53:42-54.

Souza-Filho, E. E.; Rocha, P. C., Comunello, E. \& Stevaux, J. C. 2004. Effects of the Porto Primavera dam on physical environment of the dowstream floodplain. In: Thomaz, S. M.; Agostinho, A. A. \& Hahn, N. S. eds. The Upper Paraná River and its Floodplain: Physical aspects, Ecology and Conservation. Leiden, Backhuys Publishers. p.55-74.

Souza-Filho, E. E. \& Stevaux, J. C. 2004. Geology and geomorphology of the Baía- Curutuba-Ivinhema River Complex. In: Thomaz, S. M.; Agostinho, A. A. \& Hahn, N. S. eds. The Upper Paraná River and its Floodplain: Physical aspects, Ecology and Conservation. Leiden, Backhuys Publishers. p. 1-29.

Souza, M. C.; Kita, K. K.; Romagnolo, M. B.; Tomazini, V.; Albuquerque, E. C.; Secorun, A. C. \& Miola, D. T. B. 2004. Riparian Vegetation of the Upper Paraná River Floodplain, Paraná and Mato Grosso do Sul States, Brazil. In: Agostinho, A. A.; Rodrigues, L.; Gomes, L. C.; Thomaz, S. M. \& Miranda, L. E. eds. Structure and functioning of the Paraná River and its floodplain. LTER - site 6. Maringá, EDUEM. p. 233-238.

Stevaux, J. C.; Souza-Filho, E. E. \& Martins, D. 2004. Characteristics and Dynamics of the Paraná River Channel Bedform: An Approach to Study the Influences of the Porto Primavera Dam, Sand Mining and Channel Construction. LTER - site 6 (PELD sítio 6). In: AgostinHo, A. A.; Rodrigues, L.; Gomes, L. C.; Thomaz, S. M. \& Miranda, L. E. orgs. Structure and functioning of the Paraná River and its Floodplain. Maringá, EDUEM, v. 1. p. 15-18.

Stur, E.; Fittkau, E. J. \& Serrano, M. S. 2006. Parapentaneura bentogomensis gen. n., sp. n., a new Tanypodinae (Diptera, Chironomidae) from Brazil. Zootaxa 1384:59-68.

Suriano, M. T. \& Fonseca-Gessner, A. A. 2004. Chironomidae (Diptera) larvae in streams of Parque Estadual de Campos de Jordão, São Paulo state, Brazil. Acta Limnologica Brasiliensia 16(2):129-136.

Takahashi, M. A.; Higuti, J.; Bagatini, Y. M.; Zviejkovski, I. P. \& Velho, L. F. M. 2008. Composition and biomass of larval chironomid (Insecta, Diptera) as potential indicator of trophic conditions in southern Brazil reservoirs. Acta Limnologica Brasiliensia 20(1):5-13.

Takeda, A. M.; Kobayashi, J. T.; Resende, D. L. M. C.; Funtta, D. S.; Avelino, G. S.; Fujita, R. H.; Pavan, C. B. \& Butakka, C. M. M. 2004. Influence of decreased water level on the Chironomidae community of the Upper Paraná River Alluvian Plain. In: Agostinho, A. A.; Rodrigues, L.; Gomes, L. C.; Thomaz, S. M. \& Miranda, L. E. eds. Structure and functioning of the Paraná River and its floodplain. LTER - site 6. Maringá, EDUEM. p. 101-106.

Thomaz, S. M.; Pagioro, T. A.; Bini, L. M.; Roberto, M. C. \& Rocha, R. R. A. 2004. Limnological characterization of the aquatic environments and the influence of hydrometric levels. In: THомAz, S. M.; Agostinho, A. A. \& Hahn, N. S. eds. The Upper Paraná River and its Floodplain: Physical aspects, Ecology and Conservation. Leiden, Backhuys Publishers. p. 75-102.

Trivinho-Strixino, S. \& Strixino, G. 2005. Two new species of Goeldichironomus Fittkau from southeast Brazil (Diptera, Chironomidae). Revista Brasileira de Entomologia 49:441-445. .2008. Anew species Pelomus Reiss, 1989 (Diptera: Chironomidae) from southeastern Brazil, with the description of immature stages. Boletim do Museu Municipal do Funchal 13:223-231.

2011. Larvas de Chironomidae. Guia de Identificação. São Carlos, Depto Hidrobiologia/Lab. Entomologia Aquática/UFSCar. p.39-371.

Verberk, W. C. E. P.; Siepel, H. \& Esselink, H. 2008. Life-history strategies in freshwater macroinvertebrates. Freshwater Biology $\mathbf{5 3}: 1722-1738$.

Wantzen, K. M.; Drago, E. \& Da Silva, C. J. 2005. Aquatic habitats of the Upper Paraguay river-floodplain-system and parts of the Pantanal (Brazil). Ecohydrology \& Hydrobiology 6(2):107-126. 